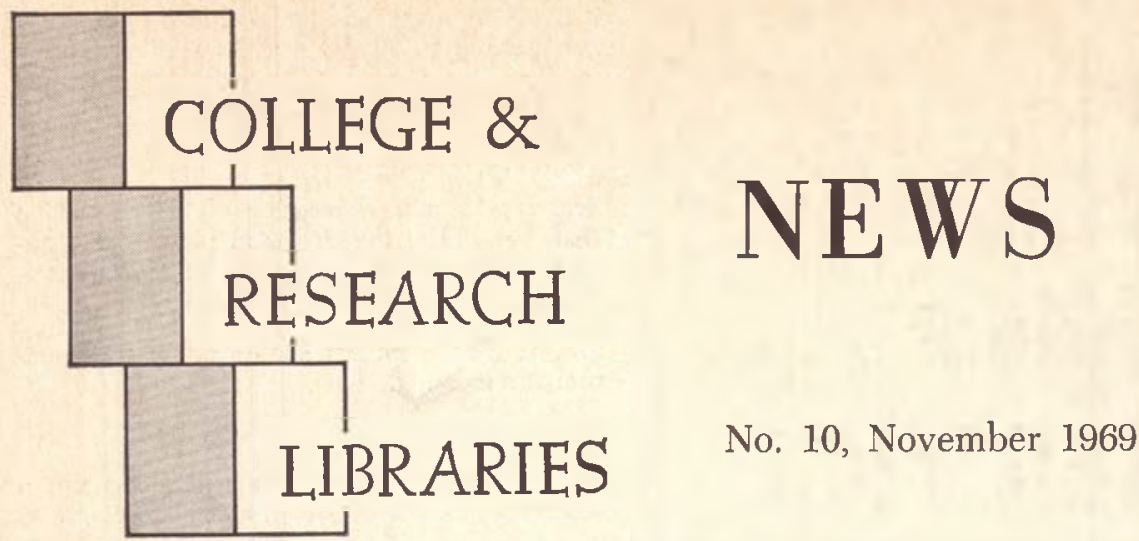

ACRL News Issue (A) of College \& Research Libraries, Vol. 30, No. 6

\title{
MINUTES OF ANNUAL MEETING, ACRL EDUCATION AND BEHAVIORAL SCIENCES SUBSECTION ATLANTIC CITY, JUNE 24, 1969
}

The retiring chairman, Mrs. Barbara Marks, Education library, New York University library, opened the meeting by welcoming the large and enthusiastic group of librarians. She presided over a brief business meeting during which she reviewed the recent founding and development of the subsection. Her feeling was that the subsection is now well established. In addition, she reported the results of the recent balloting for officers for 1969-70. Offcers include chairman, Donald Leatherman, University of Michigan; vice-chairman, Sidney Forman, Teachers College, Columbia University; and secretary, Rex Hopson, University of New Mexico.

Sign-up sheets were circulated among those present at the meeting. The lists indicated that the meeting attracted librarians from a wide range of fields: reference, social sciences, and psychology, as well as education.

The program section of the meeting consisted of two speeches and was chaired by Howard Dillon, Harvard University. Oscar Buros of the Institute of Testing, Rutgers University, spoke first, describing the publishing of the six editions of the Mental Measurements Yearbook. Making abundant use of anecdotes, he described his thirty years of work spent editing the $M M Y$. This standard reference book is put out solely by Buros, his wife, and a small clerical staff. He would like to see the Library of Congress assist in the testing field by cataloging tests and issuing LC cards for these tests.

Mrs. Priscilla Linsley, librarian of the Educational Testing Service Library, then spoke. She described the work of this library, which has been in existence since 1948. Mrs. Linsley described her specialized reference work in the field of tests. Howard Dillon then fielded questions from an interested audience which Buros and Mrs. Linsley alternated in answering.Donald Leatherman, Chairman.

Following is the Constitution for the Education and Behavioral Sciences Subsection of the ACRL Subject Specialists Section. It is to be acted upon at the Detroit Conference.

\section{ACRL Subject Spectalists Section \\ Education and Behavioral Sctences Subsection}

\section{PROPOSED BYLAWS}

\section{Article I, Name.}

The name of this organization is the Education and Behavioral Sciences Subsection of the ACRL Subject Specialists Section.

\section{Afticle II. Object.}

The subsection represents, in the American Library Association, specialists in the field of education and behavioral sciences and librarians working in these subject areas. It acts for the ACRL Subject Specialists Section, in cooperation with other professional groups, in regard to those aspects of library service that require special knowledge of education and behavioral sciences.

\section{Afticle III. Membership.}

Any member of the ACRL may elect membership in this subsection on payment of dues 


\section{The}

\section{Invisible}

\section{Product ... .} SERVICE

An invisible, intangible product goes into every shipment we send out. That product is Service.... and it costs you nothing extra. Our clientele can't see it, but they certainly are aware that they are receiving it!

We're proud of the rapid, efficient manner in which we handle your book requirements. Our huge inventory, stocked in our own warehouses ... our trained personnel ... our progressive management... these are the ingredients that make up our most desirable product-SERVICE!

Send for our brochure and terms.

\section{Taylor-Carlisle}

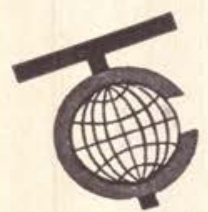

BOOKSELLERS to INDUSTRY and the ACADEMIC WORLD

MAIN OFFICE

NEW YorK: 115 East 23rd Street New York, N.Y. 10010

FLORIDA: Winter Park Mall Winter Park, Florida 32789

TeXas: Houston (opening soon) MARYLAND: M.S.C., Baltimore to ALA and any additional dues required for membership in ACRL and its sections. Every member has the right to vote. Any personal member is eligible to hold office.

\section{ARTICLE IV. Meetings.}

Sec. 1. The annual meeting of the subsection shall be held at the time and place of the annual convention of ALA, as a part of the annual meeting of ACRL.

Sec. 2. Ten members shall constitute a quorum at a meeting.

Article V. Officers.

Sec. 1. The officers of this subsection are a chairman, a chairman-elect, and a secretary.

Sec. 2. Terms of office.

(a) The chairman serves for one year.

(b) The chairman-elect serves as vicechairman for one year. At its expiration, or earlier in case of a vacancy in the office of chairman, he succeeds to the office of chairman and serves until the expiration of the term for which he was elected chairman.

(c) The secretary is elected for a term of two years.

ARticle VI. Committees.

Sec. 1. a. The Executive Committee consists of the chairman, the chairman-elect, the immediate past-chairman, the secretary, and one member-at-large appointed for one year by the chairman. The members of the Executive Committee shall be selected so as to assure representation for both education and the behavioral sciences.

b. The Executive Committee shall serve as the Program Committee with one or two additional members appointed by the chairman.

c. The Executive Committee has the authority to conduct the business of the subsection, not in conflict with any action of the Subject Specialists Section or other subsections, between meetings.

Sec. 2. The chairman may appoint special committees for specific projects or other functions which have been approved by the membership. The committees shall report to the membership through their chairman at the annual meeting.

Sec. 3. Informal discussion groups, to meet at the time of an annual conference, may be formed by the chairman or any five members. The chairman of this subsection may appoint a discussion group chairman to serve until a discussion group elects its own chairman.

Article VII. Nominations and Elections.

Sec. 1. The chairman of the subsection shall appoint a Nominating Committee to present 
candidates for the office of chairman-elect, and every second year, of secretary. Each candidate presented must have consented to his candidacy in writing and must be a member in good standing at the time of nomination.

Sec. 2. Elections shall be conducted by mail ballot in accordance with the procedures and deadlines established for ACRL. Candidates elected shall be reported at the annual meeting.

\section{Article VIII. General Provisions.}

Wherever these Bylaws make no specific provisions, the organization of, and procedure in, the Subsection shall correspond to that set forth in the Bylaws of the ACRL Subject Specialists Section.

\section{Article IX. Amendments.}

Sec. 1. Amendments to these Bylaws may be proposed in writing by the Executive Committee, or a committee appointed for the purpose, or by any five members. Proposals originating with the membership shall be filed with the secretary at least three months before the annual meeting.

Sec. 2. A copy of any proposed amendment shall be mailed by the secretary to each member at least thirty days before the annual meeting, or shall be announced in College d Research Libraries.

Sec. 3. A plurality vote of the members present and voting at an annual meeting shall carry a proposed amendment.

\section{Article X. Temporary Provisions.}

These Bylaws shall take effect upon the adjournment of the meeting at which they were adopted.

Respectfully submitted,
Bylaws Committee:
Wayne Gossage,
Chairman
Bank Street College
of Education
Toyo Kawakami
Ohio State University
Margaret Mattern
University of Rochester
Jackie Peldzus
Brooklyn College
June 25, 1968

\begin{tabular}{|c|c|}
\hline September 30,1969 & 13,601 \\
\hline September 30, 1968 & 12,931 \\
\hline September 30, 1967 & 12,226 \\
\hline
\end{tabular}

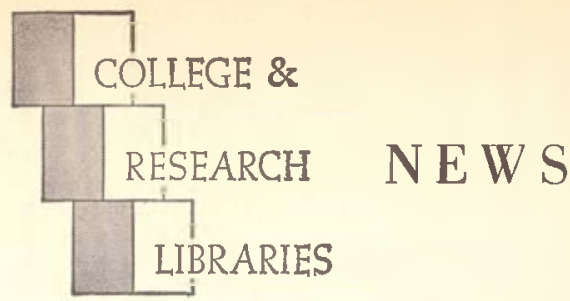

ACRL News Issue of College \& Research Libraries

News Editor, Michael Herbison, Casper College, Casper, Wyoming 82601.

Editor, Richard M. Dougherty, University of Colorado Libraries, Boulder, Colorado 80302.

Editorial Board: Richand DeGennano, Harvard University; Davio Heron, University of Kansas; ElLsworth Mason, Hofstra University; Fred Heinfutz, Southern Connecticut State College; Wriliam AxFord, Florida Atlantic University; Peten Hratr, Indiana University.

ACRL Officers, 1969/70: President, Philip J. McNiff; Chairman, College Libraries Section, John E. Scott; Junior College Libraries Section, Ruthe Erickson; Rare Books Section, Robert J. Adelsperger; Subject Specialists Section, Marcia J. Miller; Agriculture and Biological Sciences Subsection, Howard Rovelstad; Art Subsection, Wolfgang M. Freitag; Educational and Behavioral Science Subsection, Donald Leatherman; Law and Political Science Subsection, Roy M. Mersky; Slavic and East European Subsection, Joseph Placek; University Libraries Section, Roscoe Rouse.

News from the Field, Personnel profiles and notes, classified advertising, official matter of ACRL, and other material of a timely nature is published in the News issues of College \& Research Libraries.

Inclusion of an article or advertisement in CRL does not constitute official endorsement by ACRL or ALA.

Production and Advertising and Circulation office: 50 E. Huron St., Chicago, I1l. 60611. Change of address and orders for subscriptions should be addressed to College \& Research Libraries, for receipt at the above address, at least two months before the publication date of the effective issue.

Subscription to $C R L$ is included in membership dues to $A C R L$ of $\$ 6$ or more; other subscriptions to $C R L$ are $\$ 10$ per year. Neither subscriptions nor memberships include miscellaneous unscheduled supplements, which are available by purchase only. Retroactive subscriptions are not accepted. Single journal copies are available at $\$ 1.50$ each and News issues at $\$ 1.00$ each from ALA Publishing Department.

Indexed in Library Literature. Abstracted in Library Science Abstracts. Book reviews indexed in Book Review Index.

College \& Research Libraries is the official journal of the Association of College and Research Libraries, a division of the American Library Association; and is published seventeen times per year-bi-monthly as a technical journal with 11 monthly News issues, combining July-August-at 1201-05 Bluff St., Fulton, Mo. 65251 .

Second-class postage paid at Fulton, Mo. 